\title{
OBSERVATIONS ON THE RENAL THRESHOLD FOR ASCORBIC ACID IN MAN
}

\author{
By JAMES M. FAULKNER AND F. H. L. TAYLOR \\ (From the Thorndike Memorial Laboratory, Second and Fourth Medical Services (Harvard) \\ of the Boston City Hospital, and the Department of Medicine, Harvard Medical \\ School, Boston)
}

(Received for publication August 25, 1937)

Communications by Harris et al. $(1,2)$, Johnson and Zilva (3), van Eekelen (4), Hawley et al. (5), and Youmans et al. (6) have established the relationship of the output of vitamin C in the urine to the nutritional state of the organism with respect to this vitamin. They have shown that subjects maintained on diets inadequate in their vitamin $\mathrm{C}$ content, excrete only traces of ascorbic acid in the urine. Subjects living on diets containing adequate amounts of vitamin $\mathrm{C}$, however, show urinary output of the vitamin roughly proportional to the vitamin $\mathrm{C}$ intake. Harris and Ray (2) have also demonstrated that subjects in a state of vitamin $\mathrm{C}$ deprivation show no increased output of urinary ascorbic acid when a single dose of 1 gram of the vitamin is fed, while individuals who have been maintained on diets abundant in vitamin $\mathrm{C}$ excrete into the urine as much as 80 per cent of a similar test dose. Harris et al. $(1,2)$ and Johnson and Zilva ( 3 ) have designated the former group of individuals as "unsaturated" the latter as "saturated" with respect to vitamin C. The " unsaturated" group included many normal subjects whose diets were otherwise adequate, but not rich in sources of vitamin C. Some of these individuals failed to show an increased urinary output of vitamin $\mathrm{C}$ until large doses of the vitamin had been administered. Patients suffering from clinical scurvy required an even longer time to become "saturated," some of them requiring ten to eighteen days before a significant rise in the urinary ascorbic acid occurred.

The close dependence of the values for ascorbic acid in the blood serum or plasma upon the nutritional state of the organism has also been well established $(1,3,7,8)$. Low levels of serum ascorbic acid have been demonstrated in subjects suffering from vitamin $C$ undernutrition with or without manifest scurvy and in the presence of infection (9). Furthermore, van Eekelen (10) has demonstrated that "saturation" of the organism coincides with a certain level of ascorbic acid in the blood (about $1.3 \mathrm{mgm}$. per $100 \mathrm{cc}$ ) and that when this level is exceeded surplus excretion in the urine results.

This report deals with observations on the relationship of the level of blood serum ascorbic acid to the urinary output in normal individuals and in patients with scurvy and chronic infection. It deals also with the relationship of the concentration of ascorbic acid in the blood serum to the so-called saturation point, and with evidence suggesting the existence of a renal threshold for the vitamin.

\section{METHODS}

The method used for the determination of ascorbic acid in the blood was that recently published by Taylor et al. (11). To increase accuracy in titration, particularly in patients with low ascorbic acid values, the 2,6 dichlorphenol indophenol solution was sometimes diluted 1:10 with boiled distilled water. To obviate the necessity of washing, $4 \mathrm{ml}$. of the filtrate from the sodium tungstate precipitation were used in many determinations instead of using the whole $2 \mathrm{ml}$. of serum. In such instances the dilute 2,6 dichlorphenol indophenol solution was always used. Since 1936, we have also carried out in duplicate with our own methods the metaphosphoric acid technique of Farmer and Abt (8). All these three procedures gave figures which agreed within $0.2 \mathrm{mgm}$. of ascorbic acid per $100 \mathrm{ml}$. of blood serum. The method of Farmer and Abt is to be recommended if samples are to be kept overnight, or if total ascorbic acid is to be determined. In all instances 1 drop of 5 per cent $\mathrm{KCN}$ solution is added to each $5 \mathrm{cc}$. of blood to prevent oxidation. All values given as "ascorbic acid" in this communication are to be interpreted as "reduced ascorbic acid."

Samples of blood serum were precipitated immediately after the venipuncture. Except when freshly voided specimens were analyzed, all urine samples were collected in brown, glass stoppered bottles packed in ice. The preservative used for each 24-hour amount was $20 \mathrm{ml}$. of a mixture of 1 part chloroform to 2 parts glacial acetic acid. This preservative did not interfere with the titration but kept the urine bacteriostatic and definitely acid 
until the samples were analyzed. The urine titrations were made rapidly by titrating 2,6 dichlorphenol indophenol solution from a Folin burette graduated to 0.02 $\mathrm{ml}$. into the urine. The reagent contained $20 \mathrm{mgm}$. of dichlorophenol indophenol in $100 \mathrm{ml}$. of boiled distilled water. For most urines $2 \mathrm{ml}$. portions were taken for analysis and, prior to titration, $0.5 \mathrm{ml}$. of glacial acetic acid was added. For urines containing a large amount of ascorbic acid a 1:10 dilution was made previous to sampling. Analyses on both blood and urine contained in this report were made in duplicate and the figures here reported are averages of the two values.

The observations were made on a normal subject and on patients with scurvy and chronic infections. The patients suffering with chronic infection were included in the study because low serum ascorbic acid values were found in such cases. A more detailed consideration of the metabolism of vitamin $C$ in infection is the subject of another communication (9).

\section{EXPERIMENTAL}

The effect of intravenous administration of vitamin $C$ on the blood and urine ascorbic acid content. Specimens of urine and of blood serum were obtained from the fasting subject and then a fresh solution containing one gram of crystalline ascorbic acid was injected intravenously. Samples of blood and urine were obtained at frequent intervals thereafter. This procedure was carried out on one normal subject, three cases of scurvy and four cases of chronic infection. Figure 1 shows the changes in concentration of ascorbic acid in the blood of a normal individual after such intravenous therapy. The responses obtained by intravenous administration in cases of scurvy and infection were essentially the same. The serum ascorbic acid values rose rapidly to a peak following the injection of the vitamin, while the urine showed a marked rise both in concentration of ascorbic acid and in total amount excreted. In 24 hours the normal subject excreted $403 \mathrm{mgm}$., the scorbutic patient $296 \mathrm{mgm}$. and the patient with infec-

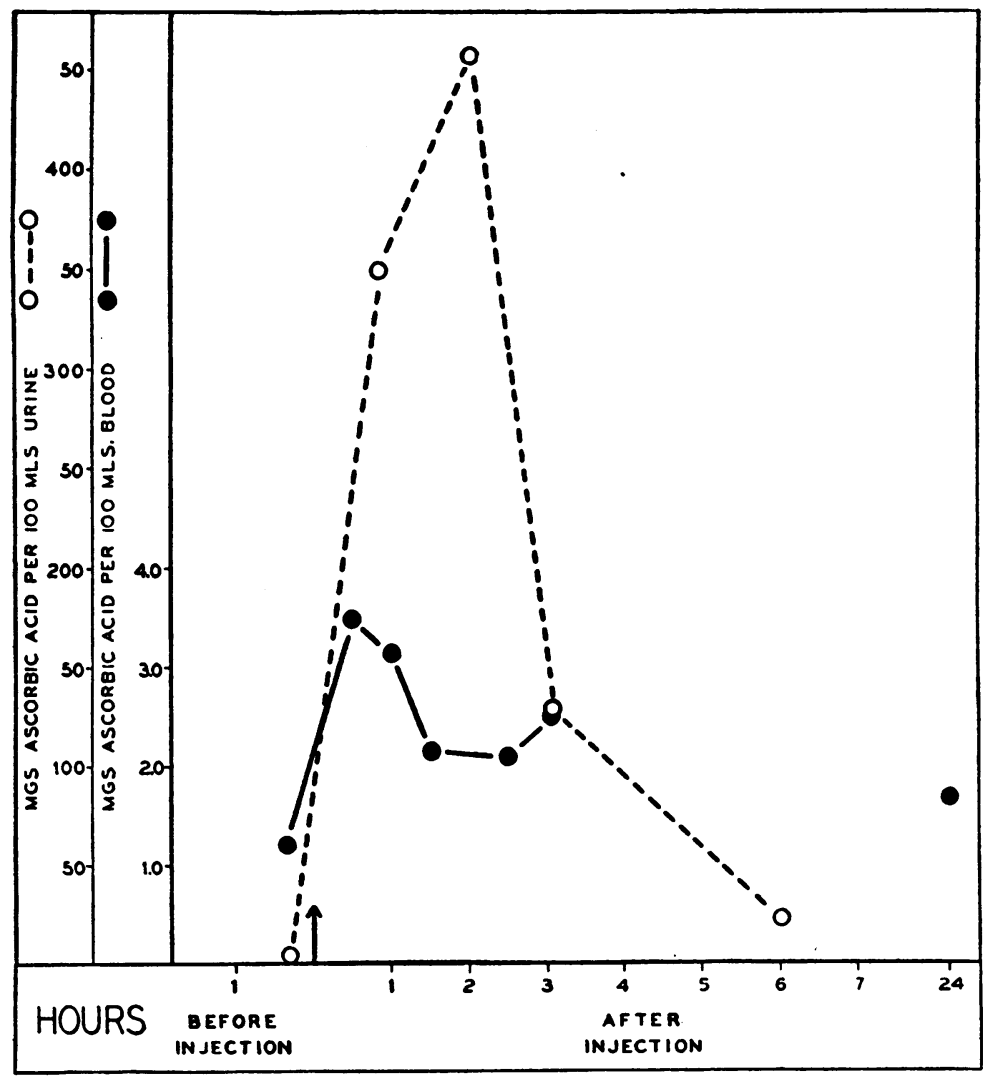

Fig. 1. Blood and Urine Levels of Ascorbic Acid in a Normal INdividual Following Intravenous Administration of One Gram of the VITAMIN 
tion $275 \mathrm{mgm}$. of the $100 \mathrm{mgm}$. injected. The normal subject continued to excrete ascorbic acid in the urine after the two patients had ceased doing so. The blood serum level of the normal individual remained above $1.70 \mathrm{mgm}$. per $100 \mathrm{ml}$. of serum at the end of 24 hours, while in the two patients it had dropped to 1.04. At some point between 1.44 and $1.04 \mathrm{mgm}$. per $100 \mathrm{ml}$. of serum in one patient and 1.63 and $1.04 \mathrm{mgm}$. in the other, the concentration of urinary ascorbic acid dropped sharply.

The effect of oral administration of vitamin $C$ on the ascorbic acid content of blood and urine. One gram of ascorbic acid was given orally to four subjects: one normal adult, two patients with scurvy and one patient with lung abscess. The results are shown in Table $I$.

Marked differences were noted between response of the normal individual and the subjects with scurvy or infection. The normal subject excreted approximately 20 per cent of the ingested amount. The two patients with scurvy each excreted 2 per cent, while the patient with infection excreted approximately 11 per cent in 24 hours.

The values for ascorbic acid in the serum of the two scorbutic patients never exceeded 1.05 mgm. per $100 \mathrm{ml}$., and the urinary excretion remained at a low level. The results in one of these cases are shown in Figure 2. In the case of the patient with a lung abscess who originally had somewhat higher blood serum ascorbic acid, there was a sharp rise in the excretion of ascorbic acid in the urine when the values of ascorbic acid in the blood serum were between 1.26 and 1.48 mgm. per $100 \mathrm{ml}$.

The effect of previous ascorbic acid therapy on the effect of administering a single dose of the vitamin orally. Table II presents data showing the effect of continued oral administration of ascorbic acid to a man suffering from a chronic infection (advanced pulmonary tuberculosis). On admission to the hospital the level of ascorbic acid in his blood serum had been $0.60 \mathrm{mgm}$. per $100 \mathrm{ml}$. but during the 12 days before the first oral tolerance was done he had received 2 oral and 1 intravenous doses of one gram each of ascorbic acid, and the serum level had risen to $0.90 \mathrm{mgm}$. per $100 \mathrm{ml}$. At this fasting level he
TABLE I

Oral tolerance for ascorbic acid

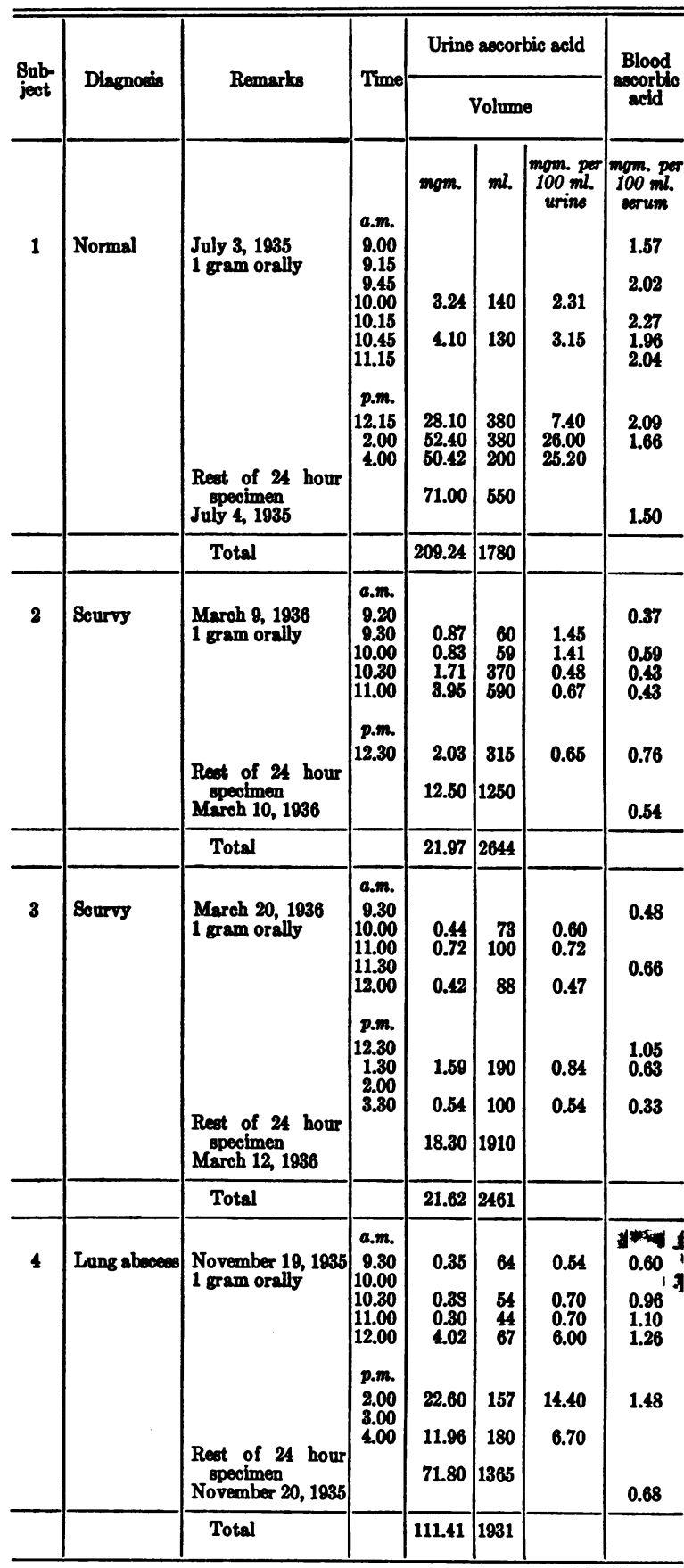

eliminated $70.74 \mathrm{mgm}$. of ascorbic acid in the urine during the 24 hours following the oral administration of one gram of ascorbic acid (Table II). Spilling of ascorbic acid into the urine occurred first when the level of ascorbic acid in the 


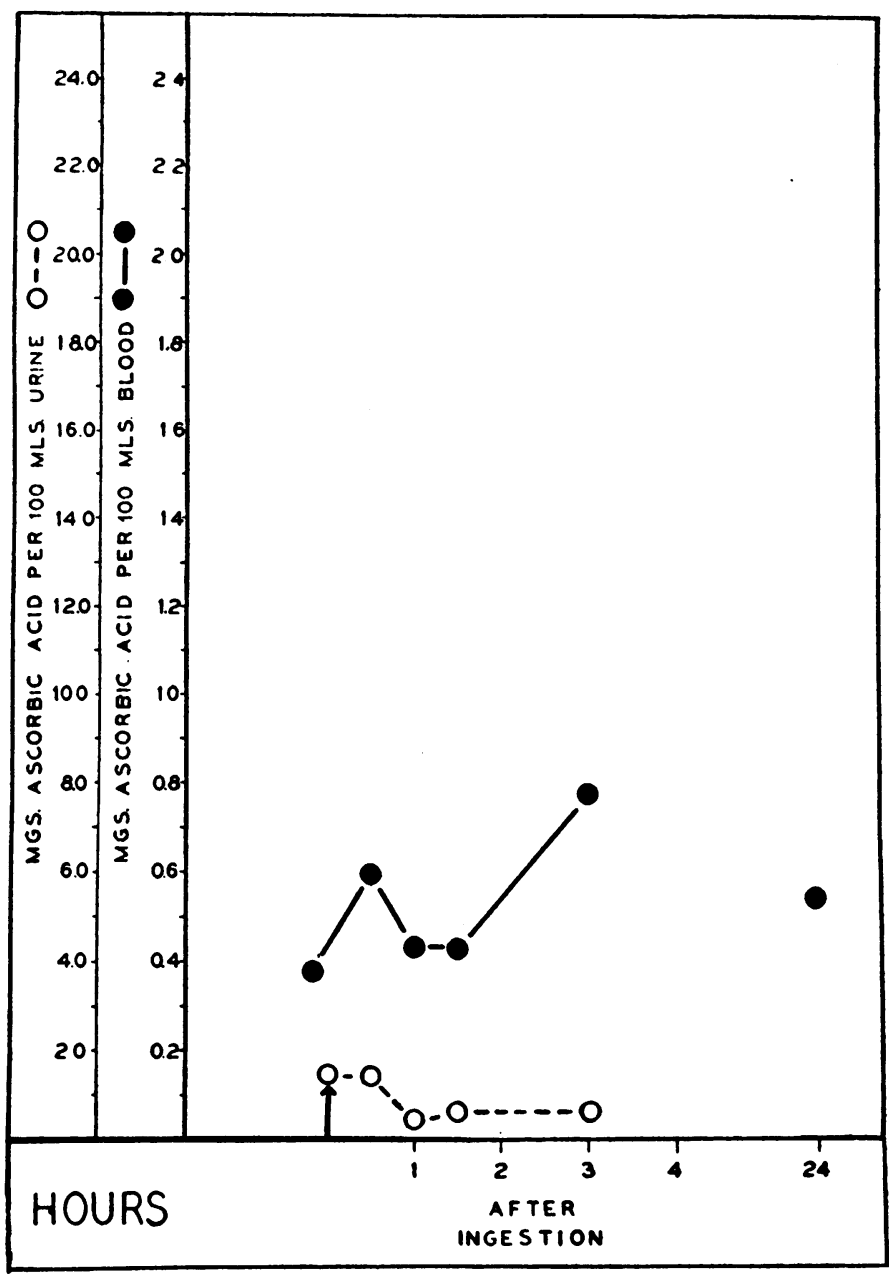

Fig. 2. Blood and Urine Levels of Ascorbic Acid in a Patient with Scurvy Following Ingestion of One Gram of the VitAMIN

blood serum lay somewhere between 1.13 and $1.74 \mathrm{mgm}$. After $500 \mathrm{mgm}$. of ascorbic acid had been given by mouth daily for 30 days the fasting serum ascorbic acid level had risen to 1.31 mgm. per $100 \mathrm{cc}$. The patient now excreted 424 mgm. of ascorbic acid in the 24 hours following the oral administration of 1 gram of the vitamin as shown in the second part of Table II. The first marked increase in concentration of the vitamin in the urine occurred when the level of ascorbic acid in the blood serum had risen to approximately $1.4 \mathrm{mgm}$. per $100 \mathrm{ml}$.

A similar analysis was obtained on a subject suffering from untreated clinical scurvy (Case 2). The initial oral tolerance to 1 gram of ascorbic acid is shown in Table I, Case 2. The level of ascorbic acid in the blood serum was 0.37 mgm. per $100 \mathrm{ml}$. and did not rise above 0.76 mgm. per $100 \mathrm{ml}$. The patient excreted in the urine an average of $8 \mathrm{mgm}$. of ascorbic acid per day and there was no definite peak in the urinary excretion. Following the 1 gram test dose a net return of only $21.9 \mathrm{mgm}$. was obtained in the urine.

The same subject was then given $300 \mathrm{mgm}$. per day of ascorbic acid by mouth together with unlimited amounts of orange juice. On this régime the ascorbic acid of the blood serum rose in the course of 10 days from an initial level of 0.32 mgm. per $100 \mathrm{ml}$. to $1.62 \mathrm{mgm}$. per $100 \mathrm{ml}$. at 
TABLE II

The effect of continued administration of ascorbic acid on the urinary excretion following the oral administration of 1 gram of ascorbic acid in a patient with pulmonary tuberculosis.

\begin{tabular}{|c|c|c|c|c|}
\hline \multirow{3}{*}{ Time } & \multicolumn{3}{|c|}{ Urine ascorbic acid } & \multirow{2}{*}{$\begin{array}{l}\text { Blood } \\
\text { as- } \\
\text { corbic } \\
\text { acid }\end{array}$} \\
\hline & \multicolumn{3}{|c|}{ Volume } & \\
\hline & $m g m$. & $m l$. & $\begin{array}{c}\text { mgm. } \\
\text { per } \\
100 \\
\text { ml. }\end{array}$ & $\begin{array}{c}m g m . \\
\text { per } \\
100 \\
m l .\end{array}$ \\
\hline
\end{tabular}

A. BEFORE ADMINISTRATION OF ASCORBIC ACID

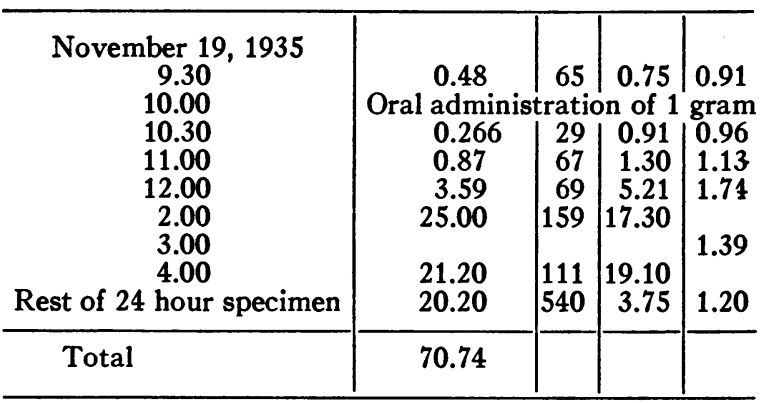

B. AFTER ORAL ADMINISTRATION OF 500 MGM. OF ASCORBIC ACID PER DAY FOR 30 DAYS

\begin{tabular}{c|c|c|c|c}
\hline $\begin{array}{c}\text { December } 18,1935 \\
9.30\end{array}$ & \multicolumn{2}{|c|}{} & \\
10.00 & No specimen & & & \\
10.30 & Oral administration of 1 & gram \\
11.30 & 2.49 & 22 & 11.3 & 1.42 \\
1.30 & No specimen & & & 1.67 \\
2.30 & 9.96 & 30 & 33.2 & 1.96 \\
3.30 & 48.80 & 59 & 83.0 & \\
Rest of 24 hour specimen & 330.00 & 47 & & 1.31 \\
\hline Total & 430 & & 1.01 \\
\hline
\end{tabular}

which point a definite increase in the urinary excretion of the vitamin was noted. On the 13th day, the serum level had reached $1.86 \mathrm{mgm}$. per $100 \mathrm{ml}$. and the urinary output $189 \mathrm{mgm}$. per day. At this time a second observation of the oral tolerance was made. After the feeding of one gram of ascorbic acid the serum level rose to $2.23 \mathrm{mgm}$. per $100 \mathrm{ml}$. and $450.7 \mathrm{mgm}$. were excreted in the urine in the succeeding 24 hours.

The contrast between the initial and final oral tolerance of this subject for ascorbic acid is typical of those obtained from 3 other cases of scurvy and 3 subjects with depleted vitamin C reserves due to infection.

Such observations as the foregoing, repeatedly confirmed, furnish strong evidence that the controlling factor in the excretion of ascorbic acid in the urine is the level of the vitamin in the blood. The evidence is further strengthened by examination of the records of patients under prolonged treatment with the vitamin. In these subjects also an increase in concentration of ascorbic acid in the urine occurred when the serum level of ascorbic acid was in the neighborhood of 1.4 mgm. ascorbic acid per $100 \mathrm{ml}$. of blood serum.

The renal threshold for ascorbic acid. Since data for calculation on the basis of over $100 \mathrm{ob}-$ servations were available, it was decided to examine all the data to determine whether the rate of excretion of the vitamin in the urine was a function of the concentration of blood serum.

The values for ascorbic acid in the urine expressed in milligrams per minute were plotted against the blood serum levels expressed in milligrams per $100 \mathrm{ml}$. of serum. From the scatter diagram so obtained, the smooth curve shown in Figure 3 was drawn. An abrupt discontinuity was found in the curve. The projection of the portion of the curve of even rate on the axis gave a value of $1.37 \mathrm{mgm}$. per $100 \mathrm{ml}$. of serum as the limiting threshold value for ascorbic acid. This value was in close approximation to the estimated value from the inspection of the results of isolated cases.

Relation of kidney threshold to the "saturation point" for ascorbic acid. The following observation indicates the relationship between kidney threshold and the so-called "saturation point." The patient cited above (Table II) was seen to be "saturated" when fed $500 \mathrm{mgm}$. of the vitamin a day. The loss into the urine was over $200 \mathrm{mgm}$. per day with this intake. The subject was then placed on a diet very low in vitamin $\mathrm{C}$ for several weeks until the level of ascorbic acid in the serum fell just below normal (0.78 mgm. per $100 \mathrm{ml}$. serum) and the urinary output to $10 \mathrm{mgm}$. per day. At this point, 100 mgm. of ascorbic acid per day were given by mouth. The blood serum level of the vitamin continued to fall during the 13 days of this therapy, and the urinary excretion remained essentially unchanged. The intake of vitamin $\mathrm{C}$ was then raised by feeding $200 \mathrm{mgm}$. a day of ascorbic acid for 17 days; for 8 days the blood serum level of ascorbic acid continued to fall, followed by a slight upward trend with very 


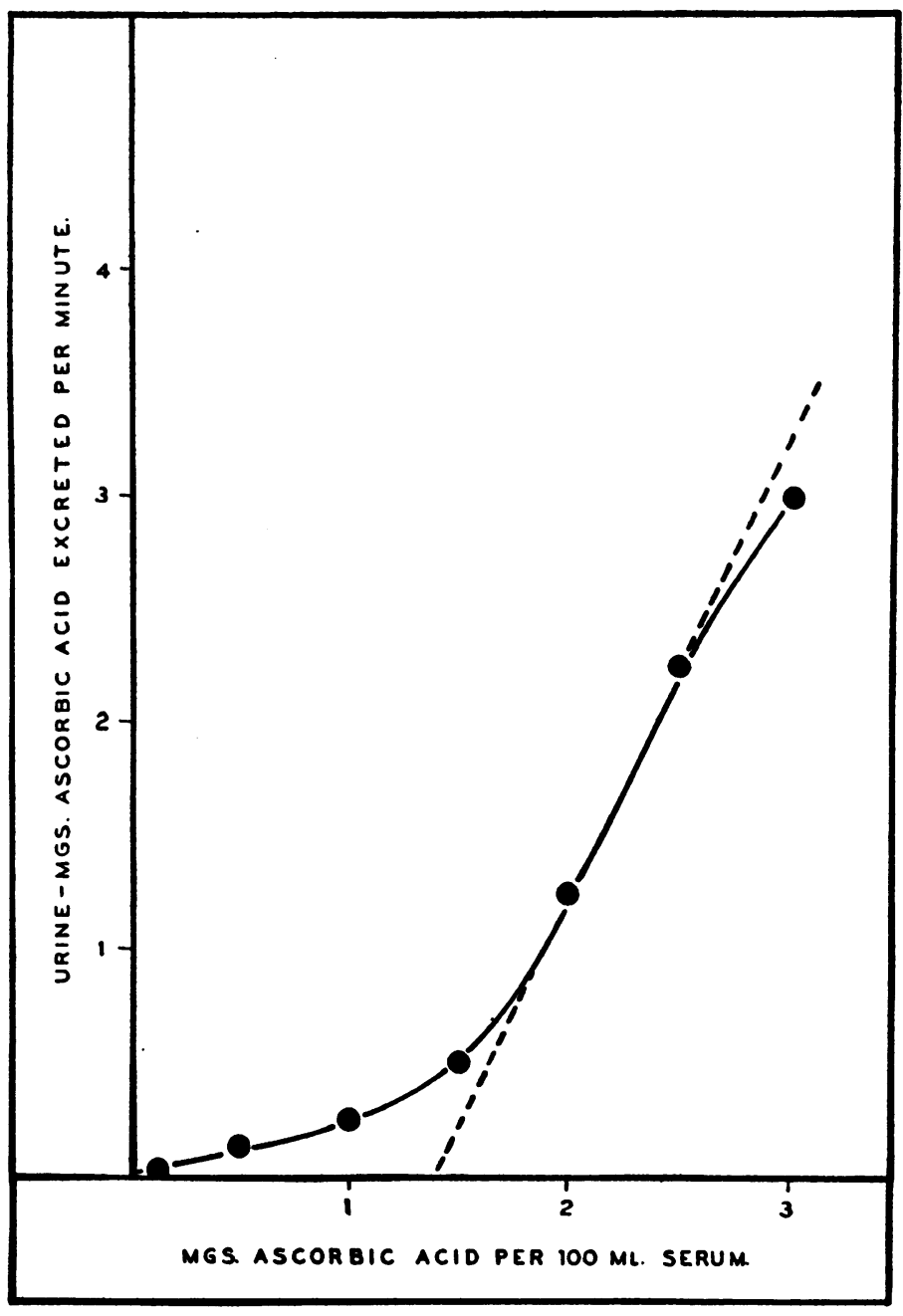

Fig. 3. The Concentration of Ascorbic Acid in the Urine as Related to its Level in the Blood Serum

slight increase of vitamin $\mathrm{C}$ in the urine. The intake was then raised to $300 \mathrm{mgm}$. per day. Under this therapy the urinary output rose and the blood serum ascorbic acid returned to normal values, reaching a level of about $1.40 \mathrm{mgm}$. per $100 \mathrm{ml}$. of serum with increased but not large urinary losses.

\section{CONCLUSIONS}

Observations were recorded which indicate that :

(1) The output of ascorbic acid in human urine is dependent upon the serum level of the vitamin.

(2) Ascorbic acid is a threshold substance with a critical level of excretion in the vicinity of $1.40 \mathrm{mgm}$. per $100 \mathrm{ml}$. serum.

(3) A maintained value of blood ascorbic acid at or above the threshold level corresponds to the so-called "saturated" state described by Harris, while ascorbic acid values below the threshold level correspond to the "unsaturated" condition.

The authors acknowledge the generous gifts of ascorbic acid from Messrs. Merck and Co., Inc., Rahway, New Jersey, and Hoffman LaRoche Co., Nutley, New Jersey.

\section{BIBLIOGRAPHY}

1. Harris, L. J., Ray, S. N., and Ward, A., The excretion of vitamin $\mathrm{C}$ in human urine and its depend- 
ence on the dietary intake. Biochem. J., 1933, 27, 2011.

2. Harris, L. J., and Ray, S. N., Diagnosis of vitamin C subnutrition by urine analysis, with note on antiscorbutic value of human milk. Lancet, 1935, 1, 71.

3. Johnson, S. W., and Zilva, S. S., The urinary excretion of ascorbic and dehydroascorbic acids in man. Biochem. J., 1934, 28, 1393.

4. Van Eekelen, M., On the metabolism of ascorbic acid (Vitamin C). Acta brev. Neerland., 1935, 5, 165.

5. Hawley, E. E., Stephens, D. J., and Anderson, G., The excretion of vitamin $C$ in normal individuals following a comparable quantitative administration in the form of orange juice, cevitamic acid by mouth and cevitamic acid intravenously. J. Nutrition, 1936, 11, 135.

6. Youmans, J. B., Corlette, M. B., Akeroyd, J. H., and
Frank, H., Studies of vitamin $\mathrm{C}$ excretion and saturation. Am. J. M. Sc., 1936, 191, 319.

7. Abbasy, M. A., Harris, L. J., Ray, S. N., and Marrack, J. R., Diagnosis of vitamin C subnutrition by urine analysis. Quantitative data-experiments on control subjects. Lancet, 1935, 2, 1399.

8. Farmer, C. J., and Abt., A. F., Determination of reduced ascorbic acid in small amounts of blood. Proc. Soc. Exper. Biol. and Med., 1936, 34, 146.

9. Faulkner, J. M., and Taylor, F. H. L., Vitamin C and infection. Ann. Int. Med., 1937, 10, 1867.

10. van Eekelen, M., On the amount of ascorbic acid in blood and urine. The daily human requirements for ascorbic acid. Biochem. J., 1936, 30, 2291.

11. Taylor, F. H. L., Chase, D., and Faulkner, J. M., Estimation of reduced ascorbic acid in blood serum and plasma. Biochem. J., 1936, 30, 1119. 